\title{
Correction to: Tumor proportion in colon cancer: results from a semiautomatic image analysis approach
}

\author{
Benedikt Martin ${ }^{1}$ (D) Bettina Monika Banner ${ }^{1} \cdot$ Eva-Maria Schäfer ${ }^{1} \cdot$ Patrick Mayr $^{1,2} \cdot$ Matthias Anthuber $^{3}$. \\ Gerhard Schenkirsch $^{4} \cdot$ Bruno Märkl ${ }^{1}$
}

Published online: 16 March 2021

(C) The Author(s) 2021

\section{Correction to: Virchows Archiv (2020) 477:185-193 https://doi.org/10.1007/s00428-020-02764-1}

The article "Tumor proportion in colon cancer: results from a semiautomatic image analysis approach", written by Benedikt Martin, Bettina Monika Banner, Eva-Maria Schäfer, Patrick Mayr, Matthias Anthuber, Gerhard Schenkirsch and Bruno Märkl, was originally published Online First without Open Access. After publication in volume 477, issue 2, page 185193 the author decided to opt for Open Choice and to make the article an Open Access publication. Therefore, the copyright of the article has been changed to (C) The Author(s) 2020 and the article is forthwith distributed under the terms of the Creative Commons Attribution 4.0 International License, which permits use, sharing, adaptation, distribution and reproduction in any medium or format, as long as you give appropriate credit to the original author(s) and the source, provide a link to the Creative Commons licence, and indicate if changes were made. The images or other third party material in this article are included in the article's Creative Commons licence, unless indicated otherwise in a credit line to the material. If material is not included in the article's Creative Commons licence and your intended use is not permitted by statutory regulation or exceeds the permitted use, you will need to obtain permission directly from the copyright holder. To view a copy of this licence, visit http://creativecommons.org/ licenses/by/4.0.

Open Access This article is licensed under a Creative Commons Attribution 4.0 International License, which permits use, sharing, adaptation, distribution and reproduction in any medium or format, as long as you give appropriate credit to the original author(s) and the source, provide a link to the Creative Commons licence, and indicate if changes were made. The images or other third party material in this article are included in the article's Creative Commons licence, unless indicated otherwise in a credit line to the material. If material is not included in the article's Creative Commons licence and your intended use is not permitted by statutory regulation or exceeds the permitted use, you will need to obtain permission directly from the copyright holder. To view a copy of this licence, visit http://creativecommons.org/licenses/by/4.0/.

Publisher's note Springer Nature remains neutral with regard to jurisdictional claims in published maps and institutional affiliations.

The online version of the original article can be found at https://doi.org/ 10.1007/s00428-020-02764-1

Benedikt Martin

benedikt.martin@uk-augsburg.de

1 Institute of Pathology and Molecular Diagnostics, University Hospital Augsburg, Augsburg, Germany

2 Department of Radiooncology, University Hospital Augsburg, Augsburg, Germany

3 Department of Visceral Surgery, University Hospital Augsburg, Augsburg, Germany

4 Tumor Data Management, University Hospital Augsburg, Augsburg, Germany 